\title{
THE SOCIALLY ENGAGED CORPORATION - ATTITUDES AND KNOWLEDGE RELATED TO COLLABORATION WITH NON-GOVERNMENTAL ORGANIZATIONS
}

\author{
Marta KARWACKA*, Karolina KITZMAN** \\ Warsaw University of Technology, Faculty of Management, Warsaw, Poland \\ *e-mail: markarwacka@gmail.com \\ **e-mail: k.kitzman@wz.pw.edu.pl
}

\begin{abstract}
Collaboration between business and non-governmental organizations (NGOs) is a relatively new phenomenon in the Polish market. It appears, however, that corporations recognized as socially responsible in Poland are starting to see greater benefits than before in collaboration with the third sector. More and more often, the collaboration involves an exchange of different resources and not merely sponsorship of specific events or social campaigns. The present study stresses the developmental aspect of the business-NGO collaboration. The collaboration by entities has been analyzed on the basis of recent literature dealing with sustainability management, Corporate Social Responsibility and businessNGO relations, and also on own research. The study discusses the conceptions of socially responsible corporations reaching new markets and customers on the basis of collaboration with NGOs.
\end{abstract}

Keywords: socially responsible corporation, corporate social objectives, non-governmental organizations, NGO, third sector, business sector, sustainability, NGO resources, benefits of collaboration with the third sector, Bottom of the Pyramid, social innovation, intersectoral relations, intersectoral collaboration, business-NGO alliances.

\section{Introduction}

"However the future unfolds, it is clear that $\mathrm{CSOs}^{1}$ will be a significant player in the new landscape of responsible governance and accountability, as both a counterbalancing force and a partner with governments and business. In fact, I believe CSOs will be the responsive glue that holds society together in the turbulent years ahead." 2

Socially engaged corporations combine several novel conceptions of economic growth as a response to the turbulent modern reality: social innovation, sustainability, or even social economy that cures the effects of economic recession. Most corporations recognized as socially responsible in Poland take up relations with non-governmental organizations (NGOs) or non-public organizations (NPOs), whose names stress their separation from activities of the state or civil society organizations, defined as organizations grouping members of civil society. The activities of the above organizations are those of the third sector, as opposed to the market and public sectors. For description and research purposes, we assume that a socially engaged corporation is an entity that follows the Corporate Social Re-

\footnotetext{
${ }^{1}$ CSO - Civil Society Organization

${ }^{2}$ Visser W. - The Age of Responsibility: CSR 2.0 and the New DNA of Business. John Wiley and Sons, Kindle Edition, p. 224.
}

sponsibility $2.0\left(\mathrm{CSR} 2.0^{3}\right)$ management strategy (in W. Visser's complex approach) or other strategies picked from the above general CSR management trend, for example: strategic philanthropy or cause-related marketing ${ }^{4}$.

Literature dealing with the socially engaged corporations, that is, for-profit entities that, within the pursuit of their business objectives, also attain social objectives (if to different extents and with varying intensity), very often takes up the issue of relations between the sector of such corporations and the NGO sector. The literature on cross-sector relations examines the relationship of entities that cooperate to their mutual benefit, the most recent publications draw attention to the development of the whole industry innovation based on collaboration between business and institutions representing the interests of consumers with different specific groups that are usually NGOs. These organizations represent the interests of specific groups: the disabled, senior citizens, or consumers of postcolonial countries. We assume that it is reasonable to explore cross-sector cooperation with an intent of the business to enter new markets and at the same time meet the needs of the beneficiaries of NGOs. It is a poorly

\footnotetext{
${ }^{3}$ Ibidem.

${ }^{4}$ Kotler P. - Corporate Social Responsibility, Doing the Most Good for Your Company and Your Cause. Wiley, 2005.
} 
studied area of cooperation, which can bring positive mutual results consistent with the nature and mission of partners from very different sectors. Besides, the described relations between the business and the NGO sector pertain not only to collaboration between different categories of entities, but also to their interaction even if such institutions never actually become partners. In this situation, we deal with a relation that is actually an encounter between the two sectors, neither of which is autonomous: instead, they each compare and draw inspiration from the other sectors' solutions. Whether it is corporations that draw inspiration from NGOs' solutions or vice versa is of no significance here. The common denominator that made the authors of selected studies into management of a socially responsible corporation take up the issue of intersectoral relations is management for sustainability interpreted as the corporation's ability to grow and survive in the changing and turbulent socio-economic environment. The building of a management strategy based generally on responsibility, for example, green responsibility or responsible building of relations with the corporation's stakeholders, fits in the new and intensely studied trend of sustainability - the corporation's responsible development for the benefit of its own and society's future. Authors such as Visser, Prahalad, or Austin, who propose business management models, consider the impact of relations between the for-profit and the not-for-profit sector on the corporation's ability to survive and constantly grow. It can be observed that such models are most adequate for the corporations that already collaborate with NGOs. Intersectoral collaboration seems to be the remedy for the changing and turbulent environment of corporations that may thus stand better chances to survive the series of shocks they encounter on the road to development. In the subsequent parts, the study will present the latest management concepts related to the cooperation of business and NGOs and then we will present the results of the study to verify the phenomenon of expanding the business into new markets through cross-sector cooperation. We analyze in the following parts of the article test results for the corporate and NGO resources and business advantages, the prospects for the development of cooperation to explore new markets, and present business evaluation of activities reaching out to new markets.

\section{Social engagement-related management conceptions: sustainability - intersectoral relations - social innovation}

One of the thematic areas related to the cooperation between the business sector and NGO sector is management in socially engaged enterprises. We assume that socially engaged companies are those that implement strategies of CSR, which is sufficiently comprehensive and included in the strategic management of the company, according to the concept of CSR 2.0 by W. Visser ${ }^{5}$. Businesses with CSR 2.0 that cooperate with NGOs on the basis of this cooperation affect strategic management. In this section, we present briefly the three most important and the latest theoretical concepts concerning the social commitment under which the company develops strategic management.

As opposed to its predecessors focused on averaging products and services, the new management era, which A. Nicholls and A. Murdock call the social innovation era, creates business models so as to respond to consumers' needs in as detailed and individualized manner as possible. Nichols and Murdock define social innovation as a response to the negative social and ecological side effects of the preceding eras ${ }^{6}$. The authors of the "social innovation" term refer to the theoretical and research contribution of C.K. Prahalad, who was the first to observe that the trend shaping the new management era, the era of social innovation, is outsourcing as the common element noticeable in analyses of the business models of different corporations. Outsourcing is omnipresent and used by multiple corporations; it is, however, special in the context of the socially engaged corporations as it frequently consists of their collaboration with NGOs. Although the actual term is not used, outsourcing appears in J.E. Austin's analysis of intersectoral collaboration, where in the described cases of collaboration between socially engaged corporations and NGOs, the corporations were involved in activities that could have been outsourced: the testing of products by NGO personnel, establishing contacts with suppliers, or development of entire distribution channels. "These activities represent the fastest growing marketing expenditure category, pumping around a half billion dollars into NPO collaborators. Many of these collabo-

\footnotetext{
${ }^{5}$ Visser W. - The Age of Responsibility: CSR 2.0 and the New DNA of Business. John Wiley and Sons, Kindle Edition, p. 36.

${ }^{6}$ Nicholls A., Murdock A. - Social Innovation: Blurring Boundaries to Reconfigure Markets. Palgrave Macmillan, New York, 2012, p. 2.
} 
rations are the participants' initial relationships and are not preceded by a philanthropic stage relationship."7

In the absence of specific relations with NGOs, such activities might also be carried out on a business-tobusiness basis. Own research also confirmed that some corporations outsource specific tasks to third sector entities. This is illustrated by a respondent's following statement: "We outsource it to Akademia Rozwoju Filantropii as we have corporate accounting and no experts in the settlement of donations, for which reason we receive support from our social partner: every now and then, we ask them over for a review to check and verify the accounts." Austin stresses that long-term collaboration with NGOs makes it possible to establish a relationship strong enough to be profitable to both parties. On the basis of various alliances, Austin analyzed the intersectoral relations to find that the most mature and sustainable form of collaboration between the for-profit and the not-for-profit sector is the integrative level, where the intersectoral relation is a strategic tool used to implement the corporation's key projects with the NGO - from the corporation's perspective accomplishing that corporation's business objectives, and the corporation - from the NGO's perspective accomplishing social objectives. At this level of collaboration, the two parties tend to strongly identify themselves with each other. Austin also distinguished two other phases: philanthropic and transactional, that may result in the corporation's reaching the integrative collaboration level. "It was recognition that cross-sector relationships come in many forms and evolve over time that led me to characterize the degree and form of interaction between nonprofits and corporations as the Collaboration Continuum." ${ }^{\prime 8}$ The corporation may also stop at the initial level of collaboration; however, the cases analyzed by Austin evidence the developmental nature of the business-NGO collaboration. Austin also noted the key role of the corporation's management in establishing alliances between business and social sector organizations. He stresses that the managers must be the authors, legitimizers, and motivators of the alliances. Without their initiative and en-

\footnotetext{
${ }^{7}$ Austin J.E. - The collaboration challenge, How non profits and business succeed through strategic alliances. Jossey-Bass, New York, 2000, p. 22.

${ }^{8}$ Austin J.E. - The collaboration challenge, How non profits and business succeed through strategic alliances. Jossey-Bass, New York, 2000, p. 20.
}

gagement, the collaboration will never reach the integrative level ${ }^{9}$.

Van den Brink ${ }^{10}$ classified the stages of development of leaders and organizations, which he treated as identical. This means that the leader's development results in the organization's development. The consecutive stages of the leader's and the organization's development correspond with each other at all levels. Van den Brink observes that the supreme phases of leadership development constitute challenges for 21 st century corporations. It is, however, recommended that such further phases of leadership development be pursued so as to build fully sustainable corporations. Also, the social innovation conception is based on mutual advantages; however; Nicholls and Murdock argue that social innovation is not only required in view of the profits derived by the corporation from collaboration, but may also help remedy market crisis situations. ${ }^{11}$ Of the three types of social innovation, the authors define incremental innovation as the one that helps remedy a diagnosed crisis through elimination of negative side effects and institutional errors occurring in a given market. Incremental innovation focuses on product and service solutions. All examples of application of incremental innovation involve the for-profit - not-for-profit relation, where the market creates the scope for corporations or NGOs that deliver services and products to consumers who would not purchase such services and products from suppliers whose offer is targeted at developed markets. The Bottom of the Pyramid $(\mathrm{BOP})^{12}$ consumers only become consumers when they get an offer tailored to their needs. As shown by examples described below, relations with NGOs combined with knowledge of BOP consumers' needs are required to create a specially tailored product for the new and so far unnoticed BOP customers. The NGO Afghanistan Institute of Learning ${ }^{13}$ offers cheap medical services owing to professional engagement of corporations in the designing and development of such services.

\footnotetext{
${ }^{9}$ Nicholls A., Murdock A. - Social Innovation: Blurring Boundaries to Reconfigure Markets. Palgrave Macmillan, New York, 2012, p. 60.

${ }^{10}$ Van den Brink M. - Individual and organizational development phases towards sustainability [in] K. Zoeteman (ed.) Sustainable Development Drivers: The Role of Leadership in Government. Business and NGO Performance, Edward Elgar, Northamton, 2012, p. 136.

${ }^{11}$ Ibidem, p. 4.

${ }^{12}$ Prahalad C.K. - The Fortune at the Bottom of the Pyramid: Eradicating Poverty Through Profits. Pearson, New York, 2009.

${ }^{13} \mathrm{http}: / /$ www.afghaninstituteoflearning.org
} 
Another example of a specially tailored product is the medical company, Aurolab ${ }^{14}$ that evolved from a charitable NGO established in 1992 and manufacturing quality lenses priced $90 \%$ below lenses sold in developed markets. Kickstart ${ }^{15}$ is an organization that assists in the formation of new businesses that offer cheap services to BOP customers. All of the above examples resulted from relations between the for-profit and the not-for-profit sector. Involved in some cases are direct relations between specific entities from the two sectors, that are alliances of such entities, while in other cases, the intersectoral relations consist of mutual inspiration to develop business solutions.

\section{Corporate and NGO resources and business advantages}

Analysis of the business-NGO collaboration may hardly leave out the issue of the parties' resources, although it has to be admitted that for many years, the relations between the business and social sector entities were based on not-too-sophisticated resources. The basic trump card of business for which the NGOs strove are funds that have always posed a serious problem in the third sector. On the other hand, NGOs had little to offer to business, thus creating their image as weak entities in need of assistance and not as potential negotiation partners.

However, the mutual perception of the two sectors has been changing for the last few years: they get to know each other and start to notice the broad range of each other's resources. As follows from Polish examples of private-social partnerships and from research projects $^{16}$, the collaboration between such entities may become much more effective if a number of resources is utilized that used to go unnoticed until quite recently. Beside the funds that always determined the decision on collaboration and still motivate NGOs today to initiate contacts with business, the third sector entities are now aware of corporations' other resources, such as: competence, contact network, or the natural openness

\footnotetext{
${ }^{14} \mathrm{http}: / /$ www.aurolab.com

${ }^{15} \mathrm{http}: / /$ www.kickstart.org

${ }^{16}$ Cf. M. Karwacka - Wspótpraca przedsiębiorstw z organizacjami pozarzadowymi jako przejaw spolecznej odpowiedzialności biznesu (Collaboration of corporations with nongovernmental organizations as a manifestation of corporate social responsibility) - quantitative research carried out from May 2011 to April 2012 for the doctor's thesis.
}

to change, and flexibility of operation ${ }^{17}$. Competencies of the business sector personnel are ever more valued by NGOs as they may simply raise the efficiency of project implementation or even NGO management. Concerned here are the typical standard skills needed to manage a corporation - definitely not the domain of third sector entities. This includes, for example, personnel, finance, and project management, or the knowledge of promotion and marketing. The business contact network is a resource that may be of great practical value for social project implementation or broader collaboration with NGOs. For NGOs, access to such network means access to further business partners, an influential group the NGO would otherwise never encounter. The ability to change, conceived as flexible involvement in new projects, is a feature that encourages NGOs to establish contacts with business - especially now that CSR is growing popular.

Also, the third sector has many resources that business failed to notice just a few years ago. They can be classified as in the case of corporations. The resource of the greatest importance in the context of collaboration with business is NGO reliability. It is mentioned by many authors who analyze relations between the private and the social sector. As follows from many research projects, Polish ones included, the social sector does enjoy big social trust; this can hardly be said of business, especially during recession. According to a 2010 diagnosis, NGOs enjoy the biggest trust in the Polish public sphere ${ }^{18}$. Further, according to the Edelman Trust Barometer 2010 report, a vast majority of respondents were more willing to trust a corporation that takes up global challenges and resolves social problems in partnership with $\mathrm{NGOs}^{19}$. Collaboration with a reliable NGO legitimizes the corporation's activities in the local community, which is tantamount to protection of its local investments. Thus a business venture implemented jointly with an NGO stands better chances of gaining the friendly attitude in the public opinion. Reconstruction of a corporation's trust and reliability

\footnotetext{
${ }^{17}$ Cf. L. S. Barlie, Alliances for Sustainable Development. Business and NGO Partnerships. Pelgrave Macmillan, London 2010. p. 44; S. Heap, NGO's and the private sector: Potential for Partnerships?, Occasional Papers Series No. 27, INTRAC 1998., p. 26

${ }^{18}$ Cf. Raport. Zaufanie Spoteczne (Social Trust. A Report). Centrum Badania Opinii Społecznej, Warsaw 2010, p. 9.

${ }^{19}$ Cf. Edelman Trust Barometer 2010 Report. Executive Summary, p. 6, available at:

http://www.lewiscommunications.com/imgs/blogentries/Edelma n_Study.pdf
} 
matters also for its perception by its staff and consumers, for the consumers' loyalty and attachment to its products, and for many other areas such as, for example, the supply chain or relations with social partners. Yet another most valuable NGO resource is competency. Many persons working for the third sector are devoted to ideas and causes in which they believe, hence their high level of competency and expertise ${ }^{20}$. Hence also probably their reliability, as people see them as those who know how to resolve specific social or local problems. The knowledge of local communities is particularly important for corporations planning to invest in a new market. Identification of social needs is extremely important to prevent the situation where the corporation's activities would fail to meet social expectations whether at the local or the global level. Close collaboration with an entity that may act as a competent social advisor or an equal partner jointly implementing a project may support the corporation's aim of reaching new markets. Just like NGOs, business also may find a contact network useful. Collaboration between entities from different sectors contributes to management of each and every venture towards development. Corporations usually operate within a relatively closed circle of entities that is limited to suppliers, business partners, competitors, etc. What makes such contacts and information so attractive is mainly their utter dissimilarity from the business standards and potential of serving as the basis for competitive advantage. It should also be mentioned at this point NGOs' connections with the government and international institutions, for example, those dealing with environmental or medical issues or human rights. As representatives of the third sector, NGOs are usually invited to participate in various social consultations and carefully heard, which may involve a specific opportunity for their collaborating corporations to influence the shape of the law. Powerful social impact is a resource that may be an advantage - as the ability to win over advocates for a project - as well as a drawback if the corporation's opponents are organized.

Business collaboration with any entity involves expectations as to specific profits. Recruited are usually qualified persons likely to yield profit for the corporation; entities that guarantee quality and appropriate pricing are selected as suppliers. Also, when deciding to estab-

\footnotetext{
${ }^{20}$ Yaziji M., Doh J. - Organizacje pozarzadowe a korporacje (NGOs and Corporations). Wyd. Naukowe PWN, Warsaw, 2011. p. 187.
}

lish collaboration with NGOs, corporations focused on the social responsibility strategy tend more and more often to be guided by the criteria of specific benefits. According to S. Waddell, "In this era of globalization and the increasingly large scale of corporate operations, this strategy holds particular attraction for medium-sized businesses that cannot easily compete in the arenas of price and service/product range. For these businesses, the long-term and local focus of NGOs can make them particularly valuable partners to develop competitive advantages." 21

Depending on the type of cooperation, the benefits may be one-dimensional or complex and multi-dimensional in nature. The potential benefits to be derived by business from the collaboration that are mentioned most often in literature include ${ }^{22}$ :

\section{- The benefit derived from a variety of ventures}

The benefit derived from a variety of ventures undertaken jointly with NGOs that is mentioned most often is strengthening of the corporation's social image. This factor is material and self-evident to the extent that not only corporations themselves admit it but also the other stakeholders, NGOs included, are aware of the benefit.

\section{- Risk management}

The benefit seems obvious in light of the various assaults on corporations, especially the global ones. Thus collaboration with NGOs may provide the corporation, on the one hand, with the feeling of being in control, and on the other hand - with access to valuable information about, for example, public feelings to which its activities or products can be adjusted so as to avoid being boycotted by consumers or NGOs. The risk management-related benefits also apply to the supply chain organization. In view of the fact that in the case of the supply chain, a corporation is liable for its own and third parties' (subcontractors') actions or for dangerous products, its relation with NGOs that control the subcontractors may save it from a scandal or ill-repute. J. Austin stresses that one of the main benefits derived

\footnotetext{
${ }^{21}$ Waddell S. - Complementary resources. The win-win Rationale for Partnership with NGOs,... op.cit. p. 203.

${ }^{22}$ Austin J.E., Reficco E. - Motivation and the Cross-Sector Alliance... op. cit.; S. Waddell, Complementary resources. The win-win rationale for partnership with NGOs [in] Terms for Endearment. Business, NGOs and Sustainable Development, ed. J. Bendell, Greenleaf Publishing, 2000, p. 197; Prahalad C. K., Hammond A. - Jak obstugiwać biednych i dobrze na tym zarabiać? (How to serve the poor and make a good profit)... op. cit.,, p. 18. 22 Yaziji M., Doh J. - Organizacje pozarzadowe a korporacje
(NGOs and Corporations), ... op. cit., p. 192.
} 
from risk management is the possibility of maintaining the status quo that is advantageous to the corporation.

- Cost reduction that may result from several reasons One of them is development, in collaboration with a competent NGO, of improvements of, for example,. the production process, or modification of work places (office premises) towards greater environmentfriendliness, which lowers the entire corporation's costs in a longer perspective. Cost reduction is also most important when designing and implementing social projects, to which NGO experts contribute their knowledge, experience, the distribution or communication channels as well as volunteers whose work and commitment assist the implementation of even the most complex ventures.

- Design and development of new products

Ever more corporations all over the world come to understand that collaboration with third sector entities may lead to many successes in the research and product development area. The NGO experts' professional knowledge is useful not only for identification of social needs but also for confrontation of the "business" with the "non-business" approach to a specific problem, and may yield innovative solutions - both wellprepared from the market perspective (the corporation's responsibility for i.e.. promotion) and carrying considerable social value (the NGO's responsibility for i.e. product safety).

- Entering new markets

Many NGOs are, by their very nature, linked to marginal communities and markets that might seem unattractive for business. However, as many corporations had the opportunity to learn, such seemingly unprofitable markets may well offer an opportunity for the corporation's growth. The attractiveness of such markets was noticed by the abovementioned author of the BOP conception, Prahalad. Many corporations have already entered such markets and scored big success there. Corporations established there offer a variety of services to the local population, such as IT education, language learning, and specialized vocational training. Financial sector corporations (as e.g. Citibank) followed the idea of the Nobel Prize winner Muhammad Yunus - the author of microfinance solutions - and also started to offer loans and financial services in BOP markets $^{23}$. Exploring new markets, the corporation may

\footnotetext{
${ }^{23}$ Ibidem, p. 8.
}

also use an NGO's distribution channels and communication systems.

- Personnel development

The employees of corporations collaborating with NGOs often discover new areas of interest, and also importantly from the business (and, especially the socially responsible business) perspective - learn the "community spirit" language and come to understand the reasons of various social problems, which eventually makes it easier for them to reach and communicate with social groups of interest.

- Gaining new and socially sensitive consumers

The fact of collaboration with a NGO tends to persuade consumers to stay loyal to such socially and/or environmentally engaged manufacturer. This is often done through so-called cause-related marketing (CRM), where upon selling its products and/or services, the corporation declares that a specific portion of its profit will be donated to a specific social purpose.

\section{- Implementation of change and creative support}

The authors of all seminar and conference pronouncements as well as publications stress the importance of innovation for competitive advantage. Many global corporations now understand that quite a lot of innovative solutions may result from collaboration with third sector entities. The social organizations' financial problems often force them to creatively utilize their resources and to apply non-standard thinking to overcome a variety of obstacles. Besides, as has been mentioned above, the complementary business and NGO resources may be combined in a most creative manner.

\section{Business-NGO collaboration as appraised by observers and the possibility of discovering new markets - study findings}

Due to the international nature of CSR as a business activity, we interviewed ${ }^{24}$ market CSR managers and observers and at the same time leaders of change in the area of social responsibility of business in Poland. A study was carried out on the basis of the above new publications on economic development of the

\footnotetext{
${ }^{24}$ Own qualitative study. A subgroup of 3 respondents selected from among the 12 managers covered by the study: observers of CSR-related trends, personnel of advisory firms and an NGO grouping socially engaged corporations.
} 
business sector that collaborates with $\mathrm{NGOs}^{25}$. The purpose of the study was to learn the opinions of observers and CSR managers on the role of collaboration with NGOs in the reaching of new markets and new customers. It was also to find out to what extent their opinions demonstrate the corporations' readiness and willingness to reach such new customers or markets. Do the CSR managers observe changes in business management within already implemented social engagement? Based on information and experience acquired in collaboration with non-profit organizations, do they contribute to attainment by the corporation of business objectives other than the gaining of new customers?

A belief prevails among the observers that collaboration with NGOs may offer a great potential for corporations forced to seek new approaches to their existing and prospective customers. With the huge number of similarly priced products and services of similar quality, the methods of gaining new customers that have been used so far are no longer effective. To quote a respondent, "business is starting to understand that the existing channels of communication with the target groups cease to work". Today, however, apart from the relatively few cases (compared to the number of corporations in Poland), the business-NGO collaboration in the area of discovering new markets is developing less dynamically than in the West. This is sure to result from the very low levels of social capital a specific foundation of any collaborative relations. According to observers, the developments in the Polish market consist in a noticeable and growing (even if still slight) nationwide percentage of successful and innovative examples of collaboration that are deserving of imitation. It seems that industry is the key element in analysis of private and social partnerships: not all corporations realize the need for collaboration with NGOs, whether solely for reputation purposes or to reach new markets. This results largely from the profile of stakeholders with which the corporations have crucial relationships.

\footnotetext{
${ }^{25}$ The study was carried out from November to December 2013, and consisted in individual medium-standardized interviews with 12 managers working solely in the Corporate Social Responsibility (CSR) area and other managers of a similar level performing other tasks as well, not only those from the CSR area. The sample included nine CSR managers, two advisers from consulting firms, and one business consultant from an NGO grouping socially responsible corporations.
}

Although they notice the big business development potential, the market observers exercise prudence when projecting fast qualitative and quantitative changes in the area of intersectoral partnerships and new markets being discovered by business owing to such alliances. According to them, a number of obstacles hinder or even hamper lasting collaboration between corporations and NGOs that would help reach new customers. For this situation to occur, it seems that both parties must be willing to learn from each other and to be open to each other's needs and objectives.

Alas! the main obstacle is the low level of social capital, which in turn generates further obstacles. According to the observers, the most noticeable obstacles include superficial nature of contacts between entities; poor research into each other's sectors; narrow conception of potential collaboration; lack of leaders with a vision; instrumental approach to collaboration; lack of promotion of the good practices; and mental obstacles. To the observers, the superficial nature of relations is reflected in the absence of any need not only to make such relations deeper but even to engage resources other than usually in the process of collaboration. NGOs hope mainly for financial support, while business - for its part - seems incapable of offering anything else. Due to such superficial approach towards the partner, the relation is likely to be short-lived, as there is no room for any serious reflection about innovative projects that might arise from engagement of the parties' different resources. According to the observers, what still prevails in Poland is quick and instrumental utilization of the partner within planned collaboration, usually for image-boosting purposes. There are but few examples of successful collaboration carried out by market leaders and treated by most as the basis for own activities. In the observers' opinion, most Polish corporations treat intersectoral collaboration as a trend that they imitate without any deeper analysis and adjustment to their own needs. The key to reach new clients and markets is to build long-term collaboration and relations based on mutual trust and loyalty; however, to quote our respondents, "there's but little long-term thinking here".

The short-sightedness can also be considered from another perspective, that is too strong a focus on one's own closest environment, needs, and organization, as well as perception of the reality from the viewpoint of one's own sector only. The observers stress that many third sector entities, while treating social activi- 
ties as justified and necessary, lack flexibility that is required to develop a joint standpoint with business, which results in the situation where "the organizations are still mainly after money". On the other hand, managers manifest a much similar attitude, perceiving the market and potential partners in the limited context of short-term business objectives. Many a time, this attitude results in a lack of elementary knowledge about the third sector, of understanding of the possible links between the two sectors, and of the need to seek innovative social solutions. In the experts' opinion, a serious problem that obstructs the road to intersectoral collaboration is the shortage of leaders. The experts agree that only managers with a vision and a broader view of the reality, going beyond their own industry and sector, would be capable of transforming the current state of affairs into a space where entities from the two sectors might establish links with each other, by means of identifying the methods of establishing such links, implementing joint projects, and contributing to such projects with engagement. It is leadership that the observers see as the remedy and means of actually changing the situation: "if leadership based on values emerges, both within NGOs and business, this will create a plane of shared values for such people to meet easily, we still suffer from a shortage of good leaders. I would like to stress the word "good" as what I mean here are deeply rooted values, methods of operation, charisma, the ability to generate social capital and responsibility for such capital."

At the same time, lack of leadership means that the need to bring the two sectors closer to each other is not developed, and efficient initiators of such change on the national scale are lacking. Although there are already some corporations in the market that treat CSR very seriously and strategically, in a vast majority of cases, we still cope with the situation where top managements see CSR-related issues as a mere trend worth imitating and not as a result of local needs aimed at collaboration towards actual benefits.

\section{$5 \quad$ Collaboration with NGOs and reaching new customers from the perspective of socially responsible corporations - study findings}

The managers confirmed that pursuing social objectives within their CSR strategy, corporations also attain a variety of business objectives, and therefore, derive from their alliances with NGOs, the experience and knowledge that can be used to implement product innovations, develop new products, or develop such products and services for new customers.

A prevalent majority of the interviewed managers noticed the impact of intersectoral collaboration on attainment of the corporation's business objectives; however, a few corporations only actually introduced product changes or reached new customers owing to their collaboration with NGOs. All examined corporations were aware of the possibility of attaining business objectives related to image and reputation through collaboration with NGOs. As appraised by the CSR managers, consistency of the activity profile of the organization with which the corporation collaborates with its social objectives is of material importance for business activities.

As follows from analysis of the managers' responses, corporations are guided by various reasons when setting the corporate social objectives. In some cases, corporations are guided solely by the social interest while in some other ones, they are guided by consistency of the organization's social objectives with the corporation's business objectives. All examined corporations collaborate with NGOs that reach people in need and at the same time, the specific corporation's potential customers. The sample included corporations where:

- the pursued social objectives followed from the nature of the corporation's business activities and were initiated by the management as an element of that corporation's strategy,

- the pursued social objectives were related to the nature of the corporation's business activities, and resulted from previously established corporation - non-profit relations based on charitable support; information about the possibility of attainment of business objectives as well was provided to the management by the manager.

On the basis of the study, two types of relations based on combination of the business with the social objectives within a corporation can be distinguished. One of the types follows from strategic management, while the other one influences strategic management.

Types of corporation - non-profit relations based on combination of the business and the social objectives (see Fig. 1). 


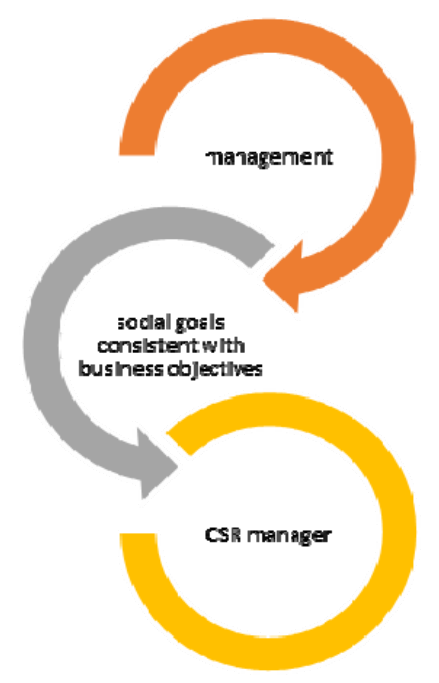

Type 1. Result of strategic management

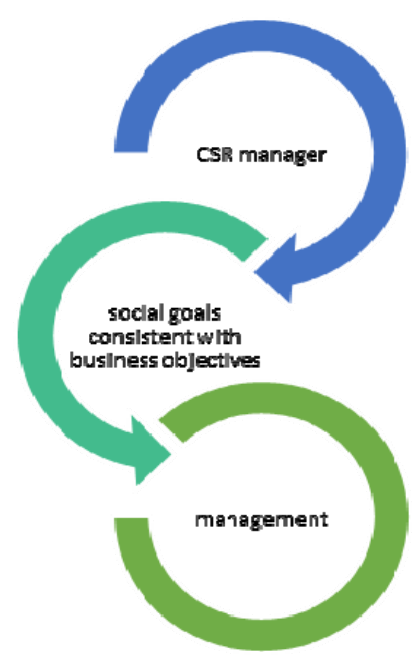

Type 2. Impact on strategic management

Figure 1. Own analysis

As appraised by the managers, the higher the consistency, the longer the collaboration aimed at pursuing social objectives together with the non-profit partner. The managers frequently mention the corporations' aim towards long-term relations within joint implementation of projects with a non-governmental partner. The managers use such terms as:

- stages of collaboration: social dialog, formulation of the needs of new consumers - the organization's beneficiaries, research into new services or products carried out by the organization; this is manifested, for example, by the following response: "It is not that we prepare and test products: we first inquire what is needed, then develop a specific conception and product and come back with it; however, we are now working towards their participation in the entire process. Such are our intentions: we are now into dialog focused on digital integration and also into projects for senior citizens."

- many years of collaboration giving professional nature to the business - non-profit relation: "Following two pilot projects, we asked the Academy to join in, developed the method together with them, invited entries for a competition, prepared a handbook - and within several years, they became our professional partner."

- mutual gaining of knowledge and experience, as described in a selected response: "Let me tell you the truth: we always say that we would never strike upon the great ideas they have; this is extremely inspiring. This is why I am always embarrassed when our colleagues - friends, actually, after so many years of collaboration - say that they have learned so much from us: like I said, this works the other way as well. For example, when developing new programs or projects internally, I largely base on the experience and knowledge obtained from them."

- assumptions as to long-term social activity without projecting the measurable effects of collaboration, absence of so-called quick-wins, lasting collaboration despite initial problems with implementation of a social project: "This is a specific long-term partnership, and what I mean is not the one and not ten years' perspective I mentioned when talking about a specific project or projects: here, I do mean such many years' collaboration. Thus I believe that such genuine partnership with NGOs is only possible in the case of corporations that follow a specific global policy, a global approach, and develop some projects globally too."

At the same time, the managers appraise long-term collaboration as:

- yielding new solutions,

- crucial in terms of impact on brand association with a specific social activity, 
- offering the possibility to acquire crucial expertise in an important area related to a specific product or service,

- involving the corporate management's big investment in innovation consisting in a quest for new "green" production processes, new manufacturers, products, and customers.

As an interesting conclusion from the study is that three types of customers can be distinguished who are reached by the corporation, whether with or without intent. It turns out that collaboration with NGOs may, first, provide the corporation with access to new customers - the social partner's direct beneficiaries (and their families); second, shape the future market; and third, help establish relations with customers being in fact the corporation's business partners. The first case involves corporations that are aware of the need to target so far marginal social groups and thus to modify their products. This happens, for example, in the settings of collaboration with organizations for people with disabilities, the sick, or the elderly. The respondents admit that market and demographic changes make them seek new market possibilities; they openly state that: "for many years, the elderly were seen as being outside a specific mainstream in all marketing surveys, target groups, target sales, etc.; today, instead, in view of the fact that society is growing old, we treat them as a new market offering new opportunities."

Other, this time prospective customers that are reached by corporations are children. This group is difficult to define explicitly in the future market category, as corporations that become involved in collaboration with NGOs supporting children seldom have projections calculated as precisely as in the former case. However, engaging their resources in projects in support of the children, the managers also consider the possibility of shaping a future consumer market. To quote a female respondent, "[if] we deal with very big projects involving millions PLN, the objectives tend to be more ambitious so to say; take a project aimed at social development of a community, involving children from small rural communities - the assumption is that if such persons go to school or receive student support, our vision is that one day they will be building consumer society as in fact our future employees or customers."

It turns out that the third group of clients that can be accessed easier through collaboration with NGOs are business partners. It turns out that an NGO grouping various business people facilitates their direct contact with one another. Meetings and relations established in the settings of joint work for a social project is definitely conducive to development of relations and to future continuation of strictly business talks. As a female respondent stresses, "The Association invited many top corporations to join the project; such corporations are our potential partners, as we have reached them in entirely different conditions, and it is much easier to talk to people you have met in settings such as collaboration within a social project instead of just visiting their office with an offer what I mean is that feeling of community, knowing that we have more in common, an objective other than just meeting the sales targets."

While in the former two cases, the reaching of customers is first and foremost to build and maintain the corporation's image, repute and trust, which may lead to relations being established with potential clients, what is crucial in the latter case are relations between the corporation and its potential customer (business partner), and its repute is of secondary importance.

Therefore, it can be concluded from the study that the CSR managers, the corporation representatives collaborating with NGOs, have knowledge about the possibilities of such collaboration. The biggest group among our respondents was persons who had been collaborating with NGOs for several years and with time, become more and more aware of the possible impact of such collaboration on the corporation's product and services change. Many managers also declared the intention to maintain the alliances to attain further business objectives likely to rank as strategic: brand recognition as responsible or influencing public decision makers regulating the specific industry. Collaboration developed at corporations whose management was interested in it and either inspired such collaboration or responded to information coming from the ranks. This confirms the observations made by Van den Brink and Austin, who associate the development of a corporation's relations with engagement of its leader. Also, our respondents stressed the leader engagement factor: "for the CSR strategy to become a genuine and actual element of the financial strategy, which is the best solution for the organization, it must be properly positioned among management's priorities. The example comes from the top: therefore, those at the top have to understand this business approach before it can actually happen." The CSR managers' high awareness and open attitudes are manifested in their statements, where 
the non-governmental partners are described as experts in the corporation's area of interest, supervisors and advisors in specific management processes. The managers declare that they carry out detailed selection of non-governmental partners from the viewpoint of their scope of activity or specialty, professionalism and transparency, and to a slight extent of their revenues and media-friendliness, which also demonstrates the experience of such managers in and methodology of collaboration with NGOs. Polish chances for intersectoral collaboration - conclusions from the study.

\section{Recapitulation}

All of the studied corporations with extended CSR strategy and many years' experience of collaboration with the non-governmental sector were international businesses, which confirm the frequent trend of introducing an example of social innovation into the international corporate policy. Even in situations where company managements utilized the experience of CSR managers, the corporate social engagement was usually initiated by the corporation's headquarters located outside Poland.

In the opinion of observers who have knowledge about the progress of such issues in developed countries, what Poland needs first and foremost are leaders with a vision. Polish society needs leaders capable of noticing the unusual potential of intersectoral collaboration. Besides, which is also strongly related to the shortage of valuable leaders, the language of the social debate on difficult issues should be changed, and hostile participants in such debates should be replaced with persons who understand the value of collaboration and joint problem-solving. One of the respondents stressed the issue he saw as important: the educational system that develops competitive instead of collaborative attitudes and promotes individuality instead of joint activity. In our opinion, the aforementioned needs would be extremely difficult to satisfy in a short time. Nevertheless, we believe that good habits and attitudes can be shaped anyway through promotion of good practices.

The interviews with CSR managers show the actual division into those who treat collaboration with NGOs as a means of business development in areas such as image and repute only, and others who perceive the potential of such collaboration and pursue specific business objectives, the reaching of new customers in- cluded. The managers were sampled from a group of about 150 socially engaged corporations in Poland, mostly international. In turn, such corporations are about one-fifth of all international corporations with representations in Poland. Therefore, the number of socially engaged corporations is rather small compared to all corporations operating in Poland, of which there are about 500. Thus our findings cannot possibly be generalized; nevertheless, we wish to stress that our purpose was to initially identify issues related to the reaching of new markets through collaboration with NGOs. It might be said that there are examples of reaching new customers through collaboration with the NGO sector; however, we treat such examples as precursory. Prompt implementation of collaboration with NGOs as a method of boosting the corporation's image taken into account, we consider it possible that private-social partnerships will be developed for the purpose of reaching new markets and customers and modifying the corporation's products and services. In our view, this direction of the corporation's development has a future; we share Austin's opinion that collaboration consisting of attainment by the parties of particular objectives may serve as an introduction to collaboration for shared objectives. Examples of such shared objectives of entities from different sectors may include: development of a product to support persons excluded from the market or sick, but provided by the corporation to such persons in the market and not philanthropic terms. Collaboration with NGOs and the resulting innovations in business thinking is a very fresh concept, which, we hope, will be discussed within intersectoral collaboration. Nevertheless, it seems consistent with the assumptions of sustainability, a trend that considers the persistence of business and sees the chances for its survival in its opening to new stakeholders and then to the offer of attaining shared objectives in partnership with such stakeholders. What we see as the premises for treating the businessNGO collaboration as a factor of strategic changes in socially responsible corporations are, first, the managers' perception of the impact of many years' collaboration, and second, the two types of collaboration related to attainment of some strategic objectives, as distinguished on the basis of the study. This is consistent with Austin's assumption that collaboration between non-governmental and business entities is a specific continuum intended to result in the partners' pursuit of shared objectives. Therefore, we point to the non-governmental partners' important resources 
and the benefits that are mentioned today become crucial in the prospective thinking about corporations' survival in a turbulent environment.

\section{$7 \quad$ References}

[1] Austin J.E. - The Collaboration Challenge: How Nonprofits and Businesses Succeed Through Strategic Alliances. Jossay-Bass, New York, 2000.

[2] Austin J.E., Seitanidi M.M. - Collaborative Value Creation: A Review of Partnering Between Nonprofits and Businesses: Part I. Value Creation Spectrum and Collaboration Stages [in] Nonprofit and Voluntary Sector Quarterly, No. 41: 726, 2012.

[3] Austin J.E., Seitanidi M.M. - Collaborative Value Creation: A Review of Partnering Between Nonprofits and Businesses: Part II. Value Creation Spectrum and Collaboration Stages [in] Nonprofit and Voluntary Sector Quarterly, No. 41: 929, 2012.

[4] Barlie L.S. - Alliances for Sustainable Development. Business and NGO Partnerships. Pelgrave Macmillan, London 2010, p. 44. Heap S. - NGO's and the private sector: Potential for Partnerships? Occasional Papers Series No. 27, INTRAC 1998.

[5] Cordes J.J. - Nonprofits and Business. The Urban Institute Press, Washington 2009.

[6] Drucker P.F. - Foundation for Nonprofit Management. Meeting the Collaboration Challenge Workbook: Developing Strategic Alliances Between Nonprofit Organizations, Wiley, San Francisco, 2002.

[7] Edelman Trust Barometer 2010 Report., Executive Summary, p. 6, available at: http://www.lewiscommunications.com/imgs/bloge ntries/Edelman_Study.pdf

[8] Harris M. - Nonprofits and Business: Toward a Subfield of Nonprofit Studies [in] Nonprofit and Voluntary Sector Quarterly, No. 41: 892, 2012.

[9] Karwacka M. - Wspótpraca przedsiębiorstw z organizacjami pozarzqdowymi jako przejaw społecznej odpowiedzialności biznesu (Collaboration of corporations with non-governmental organizations as a manifestation of corporate social re- sponsibility) - quantitative research carried out from May 2011 to April 2012 for the doctor's thesis.

[10] Kersten W., Akdanova E., Zoeteman K. - NGOs and sustainability attitudes [in] K. Zoeteman (ed.) - Sustainable Development Drivers: The Role of Leadership in Government, Business and NGO Performance, Edward Elgar, Northamton, 2012.

[11] Nicholls A., Murdock A. - Social Innovation: Blurring Boundaries to Reconfigure Markets. Palgrave Macmillan, New York, 2012.

[12] Van den Brink M. - Individual and organizational development phases towards sustainability [in] K. Zoeteman (ed.) - Sustainable Development Drivers: The Role of Leadership in Government, Business and NGO Performance, Edward Elgar, Northamton, 2012.

[13] Visser W. - The Age of Responsibility: CSR 2.0 and the New DNA of Business. Wiley, Padtstow, 2011.

[14] Waddell S. - Complementary resources. The winwin rationale for partnership with NGOs [in] Bendell J. (ed.) Terms for Endearment. Business, NGOs and Sustainable Development. Greenleaf Publishing, 2000.

[15] Seernels S. - Czas na integrujacy biznes [in] Harvard Business Review Polska, No. 111, may 2012.

[16] Schiller R.S., Almog-Bar M. - Revisiting Collaborations Between Nonprofits and Businesses: An NPO-Centric View and Typology [in] Nonprofit and Voluntary Sector Quarterly, No. 42: 942 , 2013.

[17] Prahalad C.K. - The Fortune at the Bottom of the Pyramid: Eradicating Poverty Through Profits. Pearson, New York, 2009.

[18] Prahalad C.K. - The New Age of Innovation: Driving Cocreated Value Through Global Networks. MacGraw-Hill, 2008.

[19] Raport. Zaufanie Społeczne (Social Trust. A Report). Centrum Badania Opinii Społecznej, Warsaw 2010, p. 9.

[20] Yaziji M., Doh J. - Organizacje pozarzadowe a korporacje (NGOs and Corporations). Wyd. Naukowe PWN, Warsaw, 2011. 